\title{
Elements of knowledge management in the improvement of business \\ processes
}

Renata Brajer-Marczak, Ph.D. Wrocław University of Economics

\section{Introduction}

A growing interest in the issue of process management in organizations may be observed for over twenty years in publications related to management (Bitkowska 2011, p. 14). According to S. Nowosielski (2010, p. 219), the influence on the popularity of management focus on processes currently results from two reasons: in recent years various organizations have been dealing with the improvement of processes seeing a chance to continue on the market in their optimization as well as the approval of the statement that processes are natural elements of an organization. The maturity of solutions adopted in this area depends on numerous factors which, in the simplest manner, may be divided into external and internal conditions. It is more and more often stated that the knowledge of employees, persons performing processes, enabling their efficient implementation, analysis and improvement is very important among internal conditions. As a result of its growth, process management becomes more and more professional. The literature on the subject includes a view that the effectiveness of process management implementation depends on the 
professional approach of the employees to the performed process stages and on knowledge management skills, and not on the type of conducted operations or the applied technology (Szelągowski 2016, p. 45). This study assumes that a process "is a network of activities that are repeated in time, the objective of which is to create value to external and internal customers" (Bergman, Klefsjö, 2010, p. 456). Therefore, processes are sets of activities which, according to A. Blikle (2014, p. 279), process products of a similar nature and refer to a common area of knowledge. The paradigm of process management assumes the synchronization of the work of internal units through bilateral contacts, enabling knowledge sharing and the openness towards its expansion. This knowledge should consist of collected, processed information and experience, enabling the efficient execution of processes in an organization. Explicit and tacit knowledge owned by employees makes it possible to improve the executed processes. It may thus be stated that process management defined as cross-sectional management of an entire organization where work is organized around business processes, and not functions, should be supported by the concept of knowledge management in the institutional sense where we refer to the structure of communication and information which enables the interaction between members of the organization (see Zimniewicz 2009, p. 75).

Bearing the above in mind, the study's objective is the presentation of relations between process management and the concept of knowledge management, with particular attention being paid to the improvement of processes seen through the prism of knowledge resources. The execution of the objective formulated above made use of such research methods as research on the literature on the subject related to process management and knowledge management as well as the findings from the author's own surveys conducted in 2015 among medium and lower management personnel in organizations improving processes.

\section{Knowledge and the concept of knowledge management}

A review of the available literature on the subject shows that particular authors in their discussions related to knowledge management use various definitions of knowledge. However, they all agree that knowledge is a special type of a resource in an organization which increases as it is used as opposed to other resources. It may be understood as facts, phenomena and relations between them which were consciously observed, recorded and remembered, and which may be transferred to others in order to excite certain behavior (Galata 2004, p. 50). It is strictly related to man and it may be thus stated that people are the 
main carriers of knowledge. According to E. Skrzypek (2012), knowledge, skills, abilities as well as experience form competences. For the needs of this study it was assumed, as in K.E. Sveiby, that this is the capacity to act, a result of thinking, where information is combined with understanding the information regarding the way of using it (Mikuła 2007). A knowledge-based organization, understood as the concept of management, is based to a large extent on a certain sum of knowledge owned by particular members of the organization. This knowledge is continuously enriched and developed and then used when executing various processes in the organization (Zimniewicz 2009, p. 77). M.E. Mc Gill and J.W. Slocum (1996, p. 8) suggest that the orientation of management on knowledge means discovering new ways of thinking and new perspectives as well as ensuring that the emerging new knowledge is used in practice to solve problems. A dynamic approach indicating the places of knowledge application becomes useful in this aspect. This concept assumes that employees express the readiness to learn if only they have proper conditions for this, encouraging them to analyze emerging problems, the willingness to continuously solve them in order to increase the effectiveness of the organization. The concept of knowledge management (KM) is an interdisciplinary approach, its definitions refer to information technologies, human resource management or financial aspects related to intellectual capital (Jashapara 2006, p. 27). Knowledge management is defined as any processes and activities related to creating, acquiring, separating, exchanging and using knowledge, wherever it is, in order to increase the organization's efficiency, effectiveness and the ability to learn (Davenport, Prusak, 1998). J. March (1999) proposed two approaches in the context of knowledge management: the exploitation and exploration of knowledge. According to him, the exploitation of knowledge means using it and developing the competences existing in the organization, while exploration means the pursuit of the acquisition of new competences. Therefore, the exploitation of knowledge takes place continuously, it is evolutionary, related to the dissemination, arrangement, practical use as well as the development of competences owned by the employees. Exploration is a less structuralized search for new knowledge both in the vicinity and inside the organization. It may take place in a non-linear and more revolutionary character and its effects may be remote in time. According to I. Nonaki and H. Tageuchi, the formation of new knowledge is the result of the mutual impact of explicit knowledge and tacit knowledge. Explicit knowledge is expressed in the organization's formal language, it is its property regardless of the fluctuation of employees. Tacit, quiet knowledge may be defined as follows: "we know more than we can say". Tacit 
knowledge has a cognitive nature and is difficult to transfer, it is contained in single experience, covers personal beliefs, attitudes, values and intuition. The availability and possibilities to use quiet knowledge depend on the individual holders of knowledge (Holste, Fields 2010). The transfer of tacit knowledge is slow, usually takes place through personal contacts, there often are problems with its proper interpretation.

Itisassumed thatknowledgemanagementshouldcovermutuallysupplementary stages: locating, acquiring, developing, sharing and disseminating, using and keeping knowledge (Probst, Raub, Romhardt, 2002, p. 42). Strict dependencies between them result in the fact that the impact on one of them affects others at the same time. Four aspects of knowledge management are distinguished in organizations basing their operations on knowledge: functional, process-related, instrumental and institutional (Mikuła, p. 28). They are presented in graphic form in table 1.

Table 1. Aspects of knowledge management

\begin{tabular}{|c|c|c|c|}
\hline Functional aspect & $\begin{array}{l}\text { Process-related } \\
\text { aspect }\end{array}$ & Instrumental aspect & $\begin{array}{l}\text { Institutional } \\
\text { aspect }\end{array}$ \\
\hline $\begin{array}{l}\text { Focus on the resources } \\
\text { of personalized, codified } \\
\text { and well-established } \\
\text { knowledge through } \\
\text { the execution of } \\
\text { management functions } \\
\text { in order to achieve } \\
\text { the organization's } \\
\text { objectives. This is } \\
\text { management covering } \\
\text { the execution of } \\
\text { management functions } \\
\text { in a comprehensive } \\
\text { manner at the strategic } \\
\text { level as well as } \\
\text { operational functions } \\
\text { related to identifying, } \\
\text { transferring, creating, } \\
\text { storing, connecting } \\
\text { as well as selecting } \\
\text { knowledge. }\end{array}$ & $\begin{array}{l}\text { Regulating and } \\
\text { available procedures, } \\
\text { aimed at creating } \\
\text { an appropriate } \\
\text { environment enabling } \\
\text { the efficient execution } \\
\text { of organic functions, } \\
\text { the implementation } \\
\text { of organizational } \\
\text { systems with a } \\
\text { proper structure, } \\
\text { optimizing the main } \\
\text { processes related } \\
\text { to knowledge, } \\
\text { the climate, the } \\
\text { culture and the } \\
\text { organizational } \\
\text { structure which } \\
\text { orient people } \\
\text { on developing } \\
\text { knowledge, sharing } \\
\text { it, using it properly. }\end{array}$ & $\begin{array}{l}\text { Focus on the appropriate } \\
\text { selection and use of } \\
\text { tools contributing to the } \\
\text { execution of the main } \\
\text { processes involving } \\
\text { knowledge at all levels } \\
\text { and in all areas of the } \\
\text { organization. We refer to } \\
\text { such instruments as tools } \\
\text { of the incentive system, } \\
\text { elements of the information } \\
\text { system as well as a number } \\
\text { of tools, such as: Internet, } \\
\text { Intranet, databases as } \\
\text { well as: quality circles, } \\
\text { Kaizen, brainstorming etc. } \\
\text { on which organizational } \\
\text { systems supporting } \\
\text { knowledge management } \\
\text { rely on and which are used } \\
\text { by these systems }\end{array}$ & $\begin{array}{l}\text { Identification of a } \\
\text { system of jobs and } \\
\text { employee teams at } \\
\text { the strategic and } \\
\text { operational levels } \\
\text { in the organization } \\
\text { supporting } \\
\text { knowledge } \\
\text { management, } \\
\text { identification } \\
\text { of the impact } \\
\text { of the formal } \\
\text { and informal } \\
\text { organizations } \\
\text { which execute } \\
\text { functions and tasks } \\
\text { related to process } \\
\text { management in } \\
\text { the organization } \\
\text { knowledge. }\end{array}$ \\
\hline
\end{tabular}

Source: on the basis of Mikuła 1998, pp. 318-30 


\section{Knowledge in the improvement of processes in organizations}

Each knowledge resource is important in knowledge management and it may thus be stated that this concept may perform a supporting role in the improvement of processes. The literature on the subject refers to the complementarity of various management concepts and methods (Lichtarski 2005). Knowledge acquired, developed, used and popularized by people performing processes is undoubtedly a source of competences, it may support creative attitudes, inspire new solutions in processes. In addition, knowledge on executed processes owned, developed and used by employees is one of the determinants of an organization's processrelated maturity (Skrzypek 2012, Bitkowska 2011). The process orientation implicit in the process knowledge that is possessed by the owners and users will facilitate process improvement (Reijers, 2003). Therefore, the involvement of individuals in process improvement initiatives will make it possible for them to exploit their core talents, skills, process knowledge and experience, and leverage them into process improvements (Beckett, 2004). Currently the people performing processes should not only be passively performing the commands of their superiors but they should create new knowledge using their experience, suggesting changes and introducing improvement in processes. In this way they are becoming employees of knowledge who are the key to innovation and growth in today's organization (Davenport, Iyer 2009). The execution of business processes, on the one hand, provides employees and the management personnel with knowledge and, on the other hand, becomes a platform for creating new organizational knowledge. The literature on the subject includes the idea that information related to business process should be collected and formalized in order to improve the performance of processes and consequently contribute to the development of the entire organization (Jung, Choi, Song 2007, p. 21). In connection with the above, it is important to search for a method to integrate the concept of management knowledge and the improvement of business processes so as to take advantage of the benefits from the attainable synergy effect. It is assumed that processes are used to achieve the organization's objectives, while knowledge and data are developed according to these objectives, used in processes and are also their input data. Due to the constant learning of the organization, based on the continuous selection, gathering and analysis of knowledge resources obtained during the execution of business processes, knowledge is developed and processes are improved (Tabaszewska 2009, p. 120). Proper knowledge management makes it possible to introduce changes in processes on a current basis adjusted to the organization's current knowledge on 
the customers' needs. Using the current explicit and tacit knowledge, analyzing daily actions organizations may dynamically optimize business processes as well as introduce changes of an innovative nature which organizations should particularly care about in today's world. According to researchers (Rosemann 2016, Tidd et al.,2005), after the period of focus on limiting deviations in processes, eliminating all kinds of wastage and focusing on cost reduction, the ability to introduce innovations in business processes is important today. In today's globalized world with its ever-changing economic conditions, enterprises are compelled to react to threats and opportunities in a highly flexible manner. As a consequence, it becomes a mandatory task to continuously monitor and optimize business processes towards current market requirements (Krumeich et al. 2014, p. 1). Business processes (BPs) are now considered the most valuable corporate asset (Gartner Research, 2006) and their continuous improvement has become an imperative for many business organizations. Knowledge management is recognized as an integral part of process improvement (Amarvadi, Lee, 2005), while disregarding knowledge on the needs, objectives and methods of improvement owned by employees - people performing processes, is considered the cause of failures of numerous process improvement projects (Seethamraju, Marjanovic 2009).

The idea of business process improvement (BP improvement) meets the organization's current needs where the ability to continuously adapt to the customers' changing requirements and to competition conditions is as important as current effectiveness. It is expressed in process management, understood as a systematic analysis, measurement and improvement of all organizational processes focused on the customer by means of trans-functional teams and competent employees (Czekaj 2009, p. 21). Contemporary process management has a dynamic character which is expressed in continuous attempts to introduce changes in the execution of processes. It is significant that, in practice, we are dealing with a unique chain of cooperating processes, creating a network of dependencies in which the parameters of output values are at the same time the input parameters of subsequent processes or the information base for processes performed simultaneously (Bitkowska et al.,2011, p. 8). The notion improvement is often perceived as a synonym of words: upgrading, amending, enhancing, the pursuit of "something better", achieving a higher level in "something" (www. sjp.pl). From the functional perspective, it is an action or a set of actions aimed at a condition better from the previous one from the perspective of the adopted criteria which may include time, quality, costs etc. Using the criterion of the connection between process improvement and the development strategy, we may 
distinguish strategic and operational process improvement (Cyfert 2006, p. 39). They differ in the range of activities and in the level of the allocation of activities within the management structure. In the first case, process improvement aims at adjusting the existing processes to the existing development strategy. In these types of activities, the top management as well as the so-called key employees are engaged to a significant extent. In the second case, process improvement is focused on a single strategic objective or on eliminating an identified dysfunction in the management system. Actions undertaken at this level involve, first of all, the medium and the lower level of management, including regular employees. Process improvement at the operational level, focused on the achieving of strategic objectives, comes down to their systematic improvement. It is usually inspired by the top management but it is based on the knowledge, commitment and the responsibility of employees - people performing the processes. Process management obliges employees to acquire knowledge on processes and the possibility to improve them. They should also be able to define the requirements towards their suppliers so as to use their competences to obtain the best possible process output parameters, for the execution of which they are responsible themselves. It thus requires knowledge from the employees, both individual and team knowledge, codified, but also quiet knowledge, revealed during the work of improving teams, often of a multifunctional nature. Teamwork in process improvement is of special significance due to the fact that numerous processes in the organization exceed stiff limits imposed by the organizational structure. Therefore, the following is significant from the point of view of process improvement:

- knowledge resources referring to facts and assuming the form of "a depository" of data on processes,

- resources of knowledge on cause and effect relations, significant for conducting analyses,

- knowledge resources referring to specific employee skills, taking the form of actions undertaken by them in activities regarding the introduction of changes in processes,

- resources of new knowledge making it possible to introduce anticipating changes in processes, often based on innovations.

Organizations in their practice of knowledge management may differ in approaches (Hansen, Nohira and Tierney 1999). Some of them may present the pursuit of structuring, documenting and sharing gathered knowledge as a set of information objects independent of the knowledge and experience of particular employees, namely the codification of knowledge. This approach makes it possible 
to share knowledge to all employees. In this context, knowledge is registered in order to be shared and exchanged among members of the organization. An example of such approach is the standardization of processes and documents describing their execution or the creation of a documentation repository. An intensive exchange of knowledge between employees is considered an alternative to the codification of knowledge. From this perspective, knowledge is not treated as an entry in the database, but rather the whole of experience and innovative ideas which cannot be structured in a simple manner that are exchanged every day by members of the organization. An example of such solution is building experts' network inside the organization or organizing various kinds of forms of different working meetings. In this context, we refer to the personalization of knowledge. According to the author, change introduced in processes is based on the existing knowledge (available procedures, maps of processes) but also, according to the system approach, on the need to exchange information with the participants of other processes with which a given process overlaps. The integration of knowledge on particular processes becomes a necessity. In this situation, both the codification as well as the personalization of knowledge is of critical significance. Knowledge useful to improve processes includes both explicit knowledge which is documented, unified and shared as well as tacit knowledge, deeply embedded in people's experience, usually shared in team work, in the course of problem solving where it is necessary to share the possessed experience. For this reason, tacit knowledge is sometimes defined as "experiential knowledge". Research in the field of Knowledge Management also confirms the fact that members of the organization develop new skills even when they are performing very repetitive, routine processes. Knowledge is a combination of experience, context, interpretation and reflection, it is not only processed information (Davenport, 2005). Assuming that process improvement requires a project-based approach, a typology of process knowledge, significant when introducing changes in processes, based on literature related to the area of project management, has been suggested below. The review may be found in table 2.

Table 2. Types of process knowledge

\begin{tabular}{|c|c|}
\hline Source & Type of process knowledge \\
\hline $\begin{array}{l}\text { on the basis of } \\
\text { D. Damm and } \\
\text { M. Schindler }\end{array}$ & $\begin{array}{l}\text { - knowledge on processes (methodical knowledge) } \\
\text { - knowledge in processes (knowledge of the people performing the processes) } \\
\text { - knowledge from processes (knowledge resources and experience acquired as a } \\
\text { result of introducing changes in processes) }\end{array}$ \\
\hline
\end{tabular}




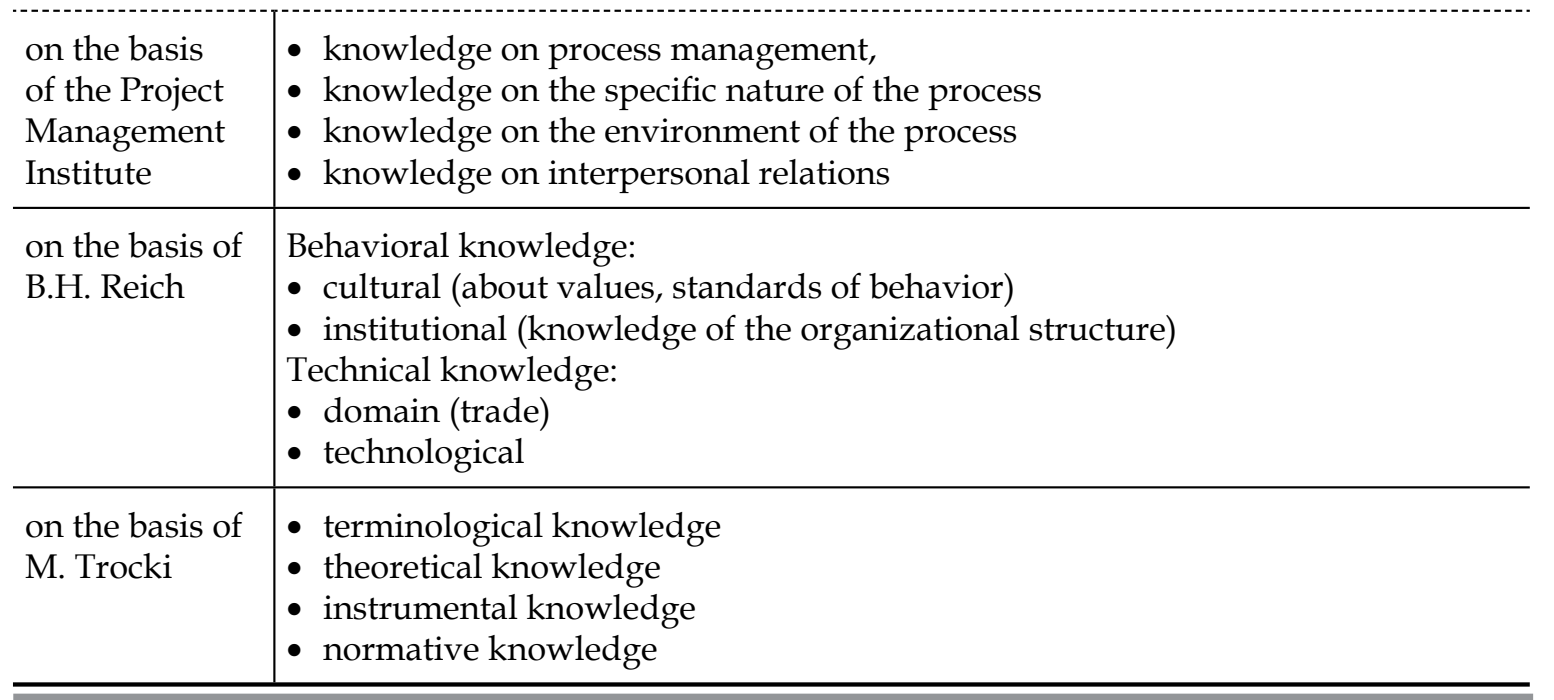

Source: own study on the basis of: Wyrozębski, Juchniewicz, Metelski 2012, pp. 50-55; Kompendium wiedzy ...3003, p. 12

\section{Characteristics of the research sample and the research methodology}

The deliberations on the practical aspect of the application of the assumptions of the concept of management knowledge in process improvement are based on a conducted survey. The research tool was an original survey which sent via e-mail to people involved in process improvement. The selection of respondents was intentional, it consisted in a subjective selection of the examined units and people. It was determined by the willingness to reach companies which are focused in management on quality, have formalized quality management systems, e.g. ISO 9000, conduct self-assessments, e.g. on the basis of the EFQM model or use various kinds of quality management tools and are thus obliged to improve the executed processes. The respondents represented companies located within the Lower Silesia region in Poland. The Computer-Assisted Selfadministered Interviewing (CASI) technique was used during the research. The survey was sent to 100 people, 25 respondents returned the filled-in complete survey also via e-mail. The conducted research did not directly concern the issue of knowledge management in the selected entities but the commitment of employees in continuous process improvement. The research was conducted between June 15 and July 26, 2015. The respondents mainly included production enterprises (24) and one transport company, important in the research sample, due to significant accomplishments in the field of process improvement, 
consistent with the EFQM model. The majority (19 examined organizations) were limited liability companies, there were five joint stock companies, and one general partnership. The majority were also companies with foreign capital, and only six respondents marked the origin of capital as domestic capital. The examined entities conduct operations of the following scope: global (19 entities), European (3 entities), domestic (3 entities). When it comes to the life cycle phase, thirteen entities are at the stage of maturity, eleven - in the phase of growth and development, and one at the beginning of its operations. When it comes to the financial situation, twelve respondents pointed out a very good situation, eight - a good situation, and five - an average situation. The research sample did not include companies with a poor or bad financial situation. In terms of employment, they were, first of all, large entities: 14 of them employed more than 1,000 people, 9 between 250 and 999 people, and only two between 50 and 149 people. All examined entities introduce improvement changes in processes. They cover both single processes (18 entities), inter-department processes (16 entities) as well as processes exceeding the formal limits of the organization, e.g. starting at the suppliers' (15 entities) or executed jointly with external customers (11 entities) ${ }^{1}$. The improvement of processes in the examined companies is related, first of all, to:

1. the identification of widely understood wastage (23 organizations),

2. the analysis of bottlenecks and wide throats in processes (18 organizations),

3. the analysis of the possibility to reduce costs (23 organizations),

4. the search for the possibility to apply new knowledge and new skills (15 organizations),

5. the search for the methods of a more precise execution of activities ( 15 entities) ${ }^{2}$.

\section{Research results}

An attempt was made to present elements of the concept of management knowledge from the perspective of process improvement on the basis of collected experiential material. T. Bertels states that the effectiveness of acquiring and using owned knowledge depends on whether the organization has joint objectives, values and whether the same language is spoken (Bertels 1996, p. 49 quoted after Zimniewicz 2009, p. 82). In turn, according to K.

1 the respondents could mark more than one answer

2 as above 
Mc Cormack and W.C. Johnson, process-related notions, such as process, input, output, owner of the process used when conducting negotiations in the organization are one of the determinants of the organization's processrelated maturity (Mc Cormack and Johnson 2003, p. 53). Respondents in the examined entities declared their knowledge of process-related terminology. They also claimed that focusing undertaken actions on the customers has a high priority. In the five-level Likert scale, in an answer to the question about these issues the respondents most often marked to a high degree (19 answers) and four answers to a high degree and two answers noticeable. Moving to the elements of the concept of management knowledge, the following opinions were examined:

- on the access to information making it possible to undertake actions improving processes,

- on receiving feedback on the assessment of submitted ideas,

- on the verification of the readiness of the information system for the improvement of processes,

- on the creation of commonly available knowledge bases on executed improvement projects,

- on the use of extranet to discuss and initiate improvement projects,

- on the general knowledge of employees on the importance of process improvement.

The above were grouped in two areas:

- the first three were defined as the flow of information enabling process improvement,

- the next three were defined as creating knowledge on the needs of process improvement.

The collected data was prepared with the use of the IBM SPSS Statistics 21 package. The package was used to analyze basic descriptive statistics and analyze reliability with Cronbach's a coefficient.

Table 3. Analysis of reliability for scales

\begin{tabular}{l|c}
\hline Area of analysis & Cronbach's a \\
\hline flow of information enabling the improvement of processes and & 0.83 \\
\hline creating knowledge on the needs of process improvement & 0.77 \\
\hline
\end{tabular}

Source: author's own studies with IBM SPSS Statistics 21 
Cronbach's coefficient $a$ is higher than the value 0.6 which indicates a satisfactory level of the internal consistency of scales taking part in the analysis.

Table 4. Basic descriptive statistics of variables measured along with the Kolmogorov-Smirnov test

\begin{tabular}{l|c|c|c|c|c|c|c|c|c}
\hline Area of analysis & $\mathbf{M}$ & Mdn & Mo & SD & Sk. & Kurt. & Min & Max & K-S \\
\hline $\begin{array}{l}\text { flow of information } \\
\text { enabling process } \\
\text { improvement }\end{array}$ & 2.76 & 2.50 & 2.00 & 0.90 & 0.33 & -1.31 & 1.50 & 4.50 & 1.20 \\
\hline $\begin{array}{l}\text { creating knowledge on } \\
\text { the needs of process } \\
\text { improvement }\end{array}$ & 3.15 & 3.00 & 2.67 & 0.99 & 0.24 & -0.51 & 1.33 & 5.00 & 0.63 \\
\hline
\end{tabular}

$M$ - average; $M d n$ - median; $M o$ - dominant; $S D$ - standard deviation; $S k$. - skewness; Kurt. - kurtosis; K-S - result of the Kolmogorov-Smirnov test

Source: author's own studies with IBM SPSS Statistics 21

Calculations included in the table indicate the fact that the average result in the analyzed areas ranges around the average assessment (3.0), provided that the flow of information enabling process improvement achieved the average value at the level of 2.76 , while creating knowledge on the needs of process improvement exceeded the average value and reached 3.15, with the standard deviation at 0.90 and 0.99 accordingly. In both cases, the kurtosis is smaller than zero which means that a high number of extreme results was obtained in the examined set, with few results similar to the average. This means that a high number of answers to a very high degree and to a very small degree was obtained during the research. The largest span was noticed in the answers to the question about the use of Intranet to discuss and initiate process improvement projects. Only one respondent answered that such tool is used to a very high degree in the examined company, and as much as eleven respondents answered that it is used to a very small degree. This is a message showing that the internal Internet network is used to a small extent to create a community focused around process improvement. This is alarming because, as is emphasized in the literature on the subject, the concept of business process management (BPM) is the convergence of the technology and theory of process management. The latest IT infrastructure supports the designing of new processes and the execution of the idea of the company's process organization 
(Chang 2006, pp. 2-11). The convergence referred to above means in practice that BPM significantly depends on information technologies the application of does not determine the application of this concept but it surely stimulates it to a significant extent. The Intranet may enable access to information in the company, integrate the IT systems already existing in the company, the computer infrastructure (hardware, the network, existing database systems) and enrich them with various tools (e.g. a platform for exchanging information, an e-learning platform). As a result, it is possible, among others, to increase the effectiveness of the knowledge and experience exchange process, respond to changing market and technological conditions faster and in a more flexible manner, improve business processes and teamwork, and e-learning applications make it possible to support the improvement of qualifications. The Intranet may also be used to disseminate knowledge on executed improvement projects. The creation of such commonly available knowledge bases in the examined entities is a little better than the average level (average 3.36), nine respondents marked the answer to a high degree, four - to a very high degree, and seven - noticeable. At this point, it should be pointed out that such "depositories" of knowledge created in organizations perform numerous functions. One of them is sharing and disseminating information on important, desired directions of thinking and action. They may also be used to increase process awareness at employees, to disseminate specific values as well as to popularize good practices with regard to process improvement, providing inspiring patterns. The uniform presentation of knowledge significantly facilitates process improvement, improves access to necessary knowledge and using it. The critical element for the distribution of knowledge is the existence of relevant communication channels as well as access to joint databases. The lack of information or hindered access to information may be a serious barrier in solving emerging problems, and sometimes even block process improvement initiatives. Information which is the content of the process is based on various data. This data should be in such format so that each authorized employee may use it. Co-workers make their actions dependent on access to information in a given moment. High quality of data, its correct configuration and distribution makes it possible to make decisions quickly and properly. Time saved in this way may be allocated for operational actions aimed at guaranteeing customer satisfaction (Mc Gill, Slocum 1996).

Employees should also be informed about benefits resulting from the introduction of changes in processes but also participate in their implementation. Access to information enabling decision-making improving processes in the 
examined entities was assessed at a level higher than the average - 3.4. The greatest number of answers accounted for the statement to a high degree (12 entities) but almost the same number of answers accounted for noticeable and to a small extent - five indications each. The answer to a very high degree was marked by three respondents. On the contrary, no respondent marked the option to a very small degree.

The obtained answers are different with regard to obtaining feedback on the assessment of submitted improvement ideas, the average of obtained grades is 3.16. The respondents most often chose the answer to a high degree (11 answers), then noticeable (8), to a small degree (5), one answer - to a very small degree. None of the examined managers marked the answer to a very high degree. The literature on the subject stresses the fact that feedback provided properly improves relations inside the organization and builds trust as well as the commitment of employees. It also gives a sense of appreciation for the undertaken effort, connected with the search for the possibility to introduce changes in processes. The sense of being appreciated is, apart from the possibility to participate, perceived as the main factor of employee commitment (Robinson et al.,2004, p. 23). Therefore, it seems that the examined entities should undertake relevant actions in this area.

The possessed knowledge and skills of employees may also be the object of improvement, such actions are undertaken by fourteen organizations in the presented research sample. In practice, this comes to widening the already existing and acquiring new knowledge needed to introduce changes in processes. The reference is made to reaching numerous sources of knowledge, filtering it, collecting and transferring among people performing various processes. Reaching knowledge related to the environment in which the organization operates is also not excluded.

\section{Conclusions}

Numerous representatives of management sciences (e.g. Senge, Prahalad, Hamel, Morgan, Crozier, Handy) believe that currently only organizations properly managing knowledge are able to meet the global competition, survive on the market and be successful. Methods of acquiring, collecting and transferring knowledge, information as well as exchanging experience become more and more important. At the same time, the attention of managers is focused on process improvement, as a consequence of dynamic changes taking place in the environment, being a key component of process management. Theneed to improve 
processes currently results, first of all, from changes in the expectations and preferences of customers, and from the conditions of competition which change more and more quickly. Regardless of the scale of changes taking place in the execution of processes, their improvement requires knowledge resources which may be provided by a knowledge management system. Both the improvement of processes as well as knowledge management is focused on creating value. In this situation, it is important to integrate knowledge management systems with the needs of process improvement. Both business processes as well as knowledge resources should be subordinated to the organization's objectives. The integration of both areas should enable the delivery of useful knowledge in proper time and collecting the knowledge in such manner so that access to the knowledge is easy and encourages undertaking improvement initiatives. Such integration makes it possible to obtain the synergy effect by appropriately shaping knowledge resources which, in turn, may be reflected in more effectively executed processes.

The conducted survey research, the results of which were referred to in the content of the study, indicates shortages related to supporting process improvement with knowledge resources. The obtained averaged results suggest an average level of adopted solutions with regard to collecting and disseminating knowledge resources on processes, while the span of answers to the asked questions was large. The examined organizations undoubtedly did not use the possibilities currently offered by internal computer networks. The creation of an internal Internet forum, through which employees share their opinions on executed process improvement projects and where they initiate such projects, takes place only in companies which are foreign branches of large corporate companies. In other entities, this tool is hardly popular. A deeper analysis of the obtained opinions also indicates the fact that people performing processes have limited access to information both on the needs of process improvement and their results. Generally accessible knowledge database are not present in all examined entities, and providing feedback on the effects of submitted improvement proposals does not have a high priority.

The author is aware of the fact that due to the small number of entities covered by the research and only one source of information (survey), the obtained results do not provide the grounds for generalizations, the presented conclusions apply only to the examined group of entities. The identified tendencies should be confirmed in research on a greater number of entities and supplemented, e.g. with interviews or the analysis of documentation. Therefore, the presented subject matter requires further exploration. 


\section{Summary}

Elements of knowledge management in the improvement of business processes

The key role in process management is played by the systematic analysis, measurement and improvement of processes. The imperative of continuous introduction of changes in processes is the answer to the changing conditions of competition and the great dynamics in the expectations and preferences of customers. Information related to business process should be collected and formalized in order to improve the execution of processes. In connection with the above, it may be stated that the improvement of processes should be supported by the concept of knowledge management in the institutional sense where we refer to the structure of communication and information which enables the interaction between members of the organization. The purpose of the study is to present relations between process management and the concept of knowledge management, with particular attention being paid to the improvement of processes seen through the prism of knowledge resources. The execution of the objective formulated above made use of such research methods as research on the literature on the subject related to process management and knowledge management as well as the findings from the author's own surveys conducted in 2015 among medium and lower management personnel in organizations improving processes.

Keywords: knowledge management, knowledge resources, business process, improvement of processes.

\section{Streszczenie}

Elementy zarządzania wiedzą w doskonaleniu procesów biznesowych

W zarządzaniu procesowymkluczową rolęodgrywa systematyczna analiza, pomiar i doskonalenie procesów. Imperatyw ciągłego wprowadzania zmian $\mathrm{w}$ procesach jest odpowiedzią na zmieniające się warunki konkurencji i dużą dynamikę oczekiwań i preferencji klientów. Informacje związane $\mathrm{z}$ procesami biznesowymi powinny być gromadzone i formalizowane, aby poprawiać wykonywanie procesów. W związku z powyższym stwierdzić można, że 
doskonalenie procesów powinno być wspierane przez koncepcję zarządzania wiedzą $\mathrm{w}$ sensie instytucjonalnym, gdzie mamy na myśli strukturę komunikacji i informacji, która umożliwia interakcję między członkami organizacji. Celem opracowania jest przedstawienie relacji pomiędzy zarządzaniem procesowym, a koncepcją zarządzania wiedzą, w szczególności zwracając uwagę na doskonalenie procesów widziane przez pryzmat zasobów wiedzy. Do realizacji wyżej sformułowanego celu wykorzystano takie metody badawcze, jak studia literatury przedmiotu z zakresu zarządzania procesowego i zarządzania wiedzą oraz wyniki własnych badań ankietowych przeprowadzonych w roku 2015 wśród kadry menedżerskiej średniego i niższego szczebla zarządzania w organizacjach doskonalących procesy.

\section{Słowa}

kluczowe: zarządzanie wiedza, zasoby wiedzy, proces biznesowy, doskonalenie

\section{References} procesów biznesowych.

1. Bergman, Klefsjö (2010), Quality from customer needs to customer satisfaction, Studentlitteratur AB, Lund.

2. Amarvadi C.S., Lee L. (2005), The dimensions of process knowledge, "Knowledge and Process Management", Vol. 12, No. 1.

3. Beckett R.C. (2004), Stimulating and evolving knowledge - oriented business process improvements in a business enterprise, "Journal of Manufacturing Technology Management", Vol. 15, No. 4.

4. Bertels T. (1996), Ideen und Konzepte, um die Lerende Organisation zu realisieren, "IO Management", No 6.

5. Bitkowska A. (ed.) (2011), Zarzadzanie procesami w przedsiębiorstwie. Aspekty teoretyczno-praktyczne, Difin, Warszawa.

6. Blikle A. (2014), Doktryna jakości. Rzecz o skutecznym zarządzaniu, Helion, Gliwice.

7. Chang J.F. (2006), Business Process Management Systems. Strategy and Implementation, Auerbach Publications, New York.

8. Cyfert Sz. (2006), Strategiczne doskonalenie architektury procesów w zarządzaniu przedsiębiorstwem, Wydawnictwo Akademii Ekonomicznej w Poznaniu, Poznań.

9. Czekaj J. (ed.) (2009), Zarzadzanie procesami biznesowymi. Aspekt metodyczny, Wydawnictwo Uniwersytetu Ekonomicznego w Krakowie, Kraków.

10. Davenport T.H., Iyer B., (2009) Should you outsource your brain? "Harvard Business Review", Februar. 
11. Davenport T.H. (2005), Thinking for a Living: How to Get Better Performance and Results from Knowledge Workers, Harvard Business School Press, Boston, MA.

12. Davenport T.H., Prusak L., (1998), Working Knowledge: How Organizations Manage What They Know, Harvard Business School Press, Boston, MA.

13. Galata S. (2004), Strategiczne zarządzanie organizacjami. Wiedza, intuicja, strategia, etyka, Difin, Warszawa.

14. Hansen M., Nohria N., Tierney T. (1999), What's your strategy for managing knowledge?, "Harvard Business Review", March-April.

15. Holste J.S., Fields D. (2010), Trust and tacit Knowledge shaving use, "Journal of Knowledge Management", vol. 14, No 1.

16. Jashapara A. (2006), Zarządzanie wiedza, PWE, Warszawa.

17. Jung J., Choi I., Song M.,(2007), An integration architecture for knowledge management systems and business process management systems, "Computers in Industry", Vol. 58.

18. Kompendium wiedzy o zarządzaniu projektami (2003), PMI, Wydawnictwo MTDC, Warszawa.

19. Krumeich J., Weis B., Werth D., Loo P. (2014), Event-Driven Business Process Management: where are we now? A comprehensive synthesis and analysis of literature, "Business Process Management Journal", Vol. 20, Iss. 4.

20. Lichtarski J. (2005), Nowoczesne koncepcje i metody zarządzania - wspólne płaszczyzny i element różnicujące, w: E. Tabaszewska, B. Rodawski (ed.), Nowoczesne koncepcje $i$ metody zarzadzania, Wydawnictwo Uniwersytetu Ekonomicznego we Wrocławiu, Wrocław.

21. March J. (1991), Exploration and exploitation in organizational learning, "Organization Science", Vol. 2, No. 1

22. Mc Cormacka K., Johnson W.C., Walker W.T. (2003), Supply chain networks and business process orientation: advanced strategies and best practices, The St. Lucie Press/ APICS Series on Resource Management, CRC Press LLC.

23. Mc Gill M.E., Slocum J.W. (1996), Das intelligente Unternehmen. Wettbewerbsvorteile durch schnelle Anpassung an Marktbedurfnisse, Stuttgart.

24. Mikuła B. (2007), Od strategicznego do operacyjnego zarzadzania wiedza, w: K. Leja, A. Szuwarzyński (ed.), Zarządzanie wiedzą. Wybrane problemy, Wydawnictwo Politechniki Gdańskiej, Gdańsk.

25. Nowosielski S. (2010), Integracja zarzadzania organizacją. Podejście procesowe, w: H. Jagoda, J. Lichtarski (red.), Kierunki i dylematy rozwoju nauki i praktyki zarzadzana przedsiębiorstwem, Wydawnictwo Uniwersytetu Ekonomicznego we Wrocławiu, Wrocław, p. 219.

26. Probst G., Raub S., Romhardt K. (2002), Zarządzanie wiedza w organizacjach, Oficyna Ekonomiczna, Kraków.

27. Reijers H.A., (2003), Design and control of Workflow Processes: Business Process Management for the Service Industry, Springer, Berlin. 
28. Robinson D., Perryman S., Hayday S., The Drivers of Employee Engagement, IES Research Report, Brighton, Sussex.

29. Seethamraju R., Marjanovic O. (2009), Role of process knowledge in business process improvement methodology: a case study, "Business Process Management Journal", Vol. 15 Iss. 6.

30. Skrzypek E. (2012), Jakościowy wymiar zarzadzania wiedza - teoria i praktyka, Zarządzanie i Finanse No. 3/1, Wydawnictwo Uniwersytetu Gdańskiego, Gdańsk.

31. Szelągowski M. (2004), Szczegótowość identyfikacji procesów i dziatań w zarządzaniu dynamicznymi procesami biznesowymi, Studia i Prace Kolegium Zarządzania i Finansów, Szkoła Główna Handlowa Iss. 49.

32. Tabaszewska E. (2009), Zarzadzanie wiedza zorientowane na procesy biznesowe - podstawowe założenia, w: S. Nowosielski (ed.), Podejście procesowe w organizacjach, Wydawnictwo Uniwersytetu Ekonomicznego we Wrocławiu, Wrocław.

33. Tidd J., Bessant J., Pavitt K. (2005), Managing Innovation, Beret-Kohler Publisher, San Francisco.

34. Wyrozębski P., Juchniewicz M., Metelski W. (2012), Wiedza, dojrzałość, ryzyko w zarządzaniu projektami. Wyniki badan, Oficyna Wydawnicza SGH w Warszawie, Warszawa.

35. Zimniewicz K. (2009), Wspótczesne koncepcje i metody zarządzania, PWE, Warszawa.

36. Website: www.gartner.com, Gartner Research (2006), "Gartner position on business process management" (20.08.2016 - access date)

37. Website: www.sjp.pwn.pl/slowniki/doskonalenie.html (24.08.2016 access date) 